\title{
Forage-pasture production in the first three years of an agroforestry experiment
}

\author{
K.M. POLLOCK, R.J. LUCAS, D.J. MEAD and S.E. THOMSON \\ Department of Plant Science, Lincoln University, PO Box 84, Canterbury, New Zealand
}

\begin{abstract}
Forage production from a newly established pinepasture system at 1000 trees per ha and pasture alone was compared. Pastures of ryegrass/clover, cocksfoot/clover, phalaris/clover and lucerne were used. Overall, forage production varied little between the grass/clover pastures and was little affected by the pine trees except for the $14 \%$ reduction in pasture area in the trees because of herbicide-treated planting strips. Lucerne production between the trees was similar to that of the grass/clover pastures but in the open pasture, lucerne yielded a total of $29.5 \mathrm{t} \mathrm{DM} / \mathrm{ha}$ compared with $22 \mathrm{t} \mathrm{DM} / \mathrm{ha}$ from grass/clover treatments. Pasture growth within $1 \mathrm{~m}$ of the trees in the third summer was reduced by as much as $40 \%$, indicating that competitive dominance was shifting in favour of the pines.
\end{abstract}

Keywords: agroforestry, competition, pasture-tree interaction, radiata pine, temperate pasture

\section{Introduction}

Planting trees on improved pasture has become a common land use practice in recent years as a means of income diversification and/or erosion control. Trees may be planted at high population densities for farm woodlots or low densities to allow grazing of the pasture until tree canopy closure at $10-15$ years. Whatever management regime is adopted some grazing is normally available from year two or three when trees are large enough-to resist grazing-damage.-On-flatter sites forage harvesting is an option prior to grazing.

Pasture can provide strong competition against young trees so it is essential to create and maintain planting spots or strips free of pasture and weeds. Intense competition can be expected once the tree and pasture roots meet and the tree canopy develops. Several studies in New Zealand (Cossens 1984; Percival et al. 1984; Percival \& Knowles 1988; Knowles et al. 1992) indicate that pasture productivity is little affected until trees are 3 or 4 years of age, after which the effect on pasture is related to tree density and crown size.

The Lincoln University agroforestry experiment was established in 1990 to study production and competitive processes between pine trees and pasture species in a temperate sub-humid environment. Mead et al. (1993) have described the experiment and the first two years' performance of the five Pinus radiata types in some detail. This paper is concerned with pasture production and composition, and the effect that trees may have on pasture during the first three years under a regime of forage harvesting prior to introducing sheep in late September 1993.

\section{Methods}

The site and experimental design are described in detail by Mead et al. (1993) and briefly restated below.

\section{Site}

The experiment was $2 \mathrm{~km}$ from Lincoln University on a Templeton silt loam soil consisting of 1-2 $\mathrm{m}$ of fine alluvial sediments over gravels. The climate is temperate and sub-humid. Figure 1 shows the long term monthly temperatures and precipitation along with the monthly mean values for 1990-93.

\section{Experimental}

The experiment was in two parts. Experiment A consisted of pasture with trees and experiment B pasture only. The trees were planted in July 1990. Pasture was sown in late September 1990 with no additional fertiliser following a crop of vining peas the previous summer. To ensure good tree establishment, $1 \mathrm{~m}$ wide strips were sprayed with hexazinone at $2.5 \mathrm{~kg}$ a.i./ha later in the spring and again in spring 1991.

Experiment A was a split-plot, randomised block design-with 3 replications.-It occupied 5.2-ha-including rows of guard trees. The 0.194 ha main plots consisted of $\mathbf{5}$ pasture types and a bare ground treatment. Pastures sown (kg seed per ha in brackets) were: 1 . Yatsyn perennial ryegrass (Lolium perenne) (13) + clovers: Grasslands Pawera red (Trifolium pretense) (6), Grasslands Huia white (T. repens) (2) and Woogenellup subterranean ( T. subterranean) (10); 2. Grasslands Wana cocksfoot (Dactylis glomerata) $(10)+$ clovers; 3 . Grasslands Maru phalaris (Phalaris aquatica) (8) + clovers; 4. Yatsyn perennial ryegrass (13) without legume; 5. WL320 lucerne (Medicago sativa) (8); and 6. Bare ground. Treatment 4 was originally sown in Grasslands Maku lotus (Lotus pedunculatus) which did 
Figure 1 Monthly mean temperatures and monthly precipitation totals from Lincoln meteorological station.

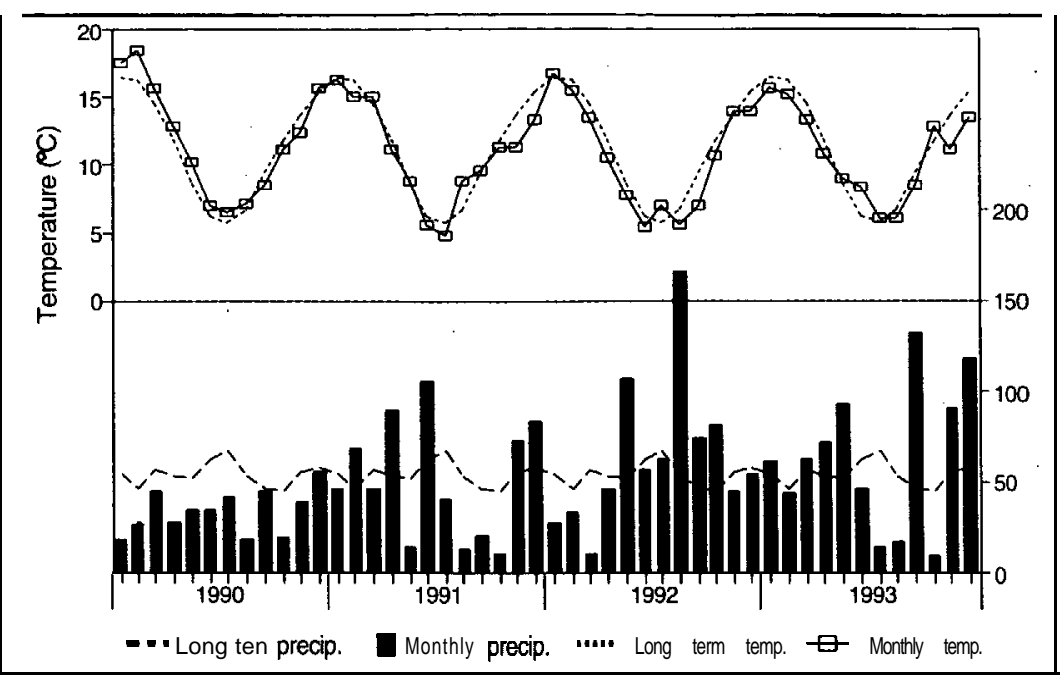

not establish. It was resown to ryegrass without legume in autumn 1992. For this study, the treatment was essentially volunteer weeds dominated by wireweed (Polygonum aviculare) for year 1 and 2 (no data taken). The ryegrass used was a high endophyte (Acremonium lolii) type.

Trees were planted in rows in an east-west direction with $7 \mathrm{~m}$ between rows and $1.4 \mathrm{~m}$ between trees giving an initial density of 1000 trees/ha. Thinning in late 1992 reduced this to 800 trees/ha. Thinning will take place in subsequent years until a final stocking of 200 trees/ha is reached. The sub-plots consisted of 5 different tree types of radiata pine (refer to Meadet al. (1993) for details). This study is not concerned with the effects of tree types. However, sub-plots of pasture in relation to distance from tree rows were studied (see below).

Experiment $\mathrm{B}$ was located directly to the east of experiment $\mathrm{A}$ and was a randomised block design on 1 ha including space for stock races. The plots were 0.049 ha. Pasture types were the same as in experiment A but the bare ground was replaced by a sixth pasture type which is not reported here.

\section{Pasture measurement}

Forage was harvested twice in year 1 (22 January and 16 May 1991), 3 times in year 2 (16 October 1991, 16 December 1991 and 19 January 1992), and 3 times in year 3 (30 October 1992, 9 December 1992 and 3 February 1993). At each cutting dry weight production and composition was determined by weighing 10-20 $\mathrm{m} 2$ of freshly mown herbage from each plot followed by selecting a $500 \mathrm{~g}$ sub-sample for separation into legume, grass, other plants and dead material before drying to a constant weight at $80^{\circ} \mathrm{C}$.

In experiment $\mathrm{A}$ just prior to the last forage harvest, a single-probe pasture capacitance meter was used to measure the growth differential of the pasture relative to distance south and north of tree rows. Probe measurements were taken at $0.9 \mathrm{~m}$ south of tree rows, $1.8 \mathrm{~m}$ south of tree rows, midway between tree rows (centre), $1.8 \mathrm{~m}$ north of tree rows and $0.9 \mathrm{~m}$ north of tree rows. The probe was calibrated by taking 6 sets of probe readings for each pasture type from the same location as the forage production samples, then regression analysis was used to get the relation between probe readings and the dry weights of the cut forage.

Pasture regrowth and accumulation after the last forage harvest was monitored using a pasture capacitance probe on 22 March, 5 May, 23 June and 30 September 1993. Readings were taken at the same positions as above to allow comparisons of pasture production in relation to distance from the tree rows. The capacitance probe was calibrated to dry weights of 8-10 clipped samples for each pasture type at each measurement date.

\section{Treemeasurements}

Tree heights and stem base diameter were measured each winter and diameter at $1.4 \mathrm{~m}$ above ground level (DBH) in the winter of 1993.

\section{Data analysis}

Statistical analysis was carried out using ANOVA and GLM procedures. Relative growth rate data were log- 
Table 1 Mean forage harvest yield ( $\mathrm{DM} / \mathrm{ha}$ ) of pastures in the first 3 years.

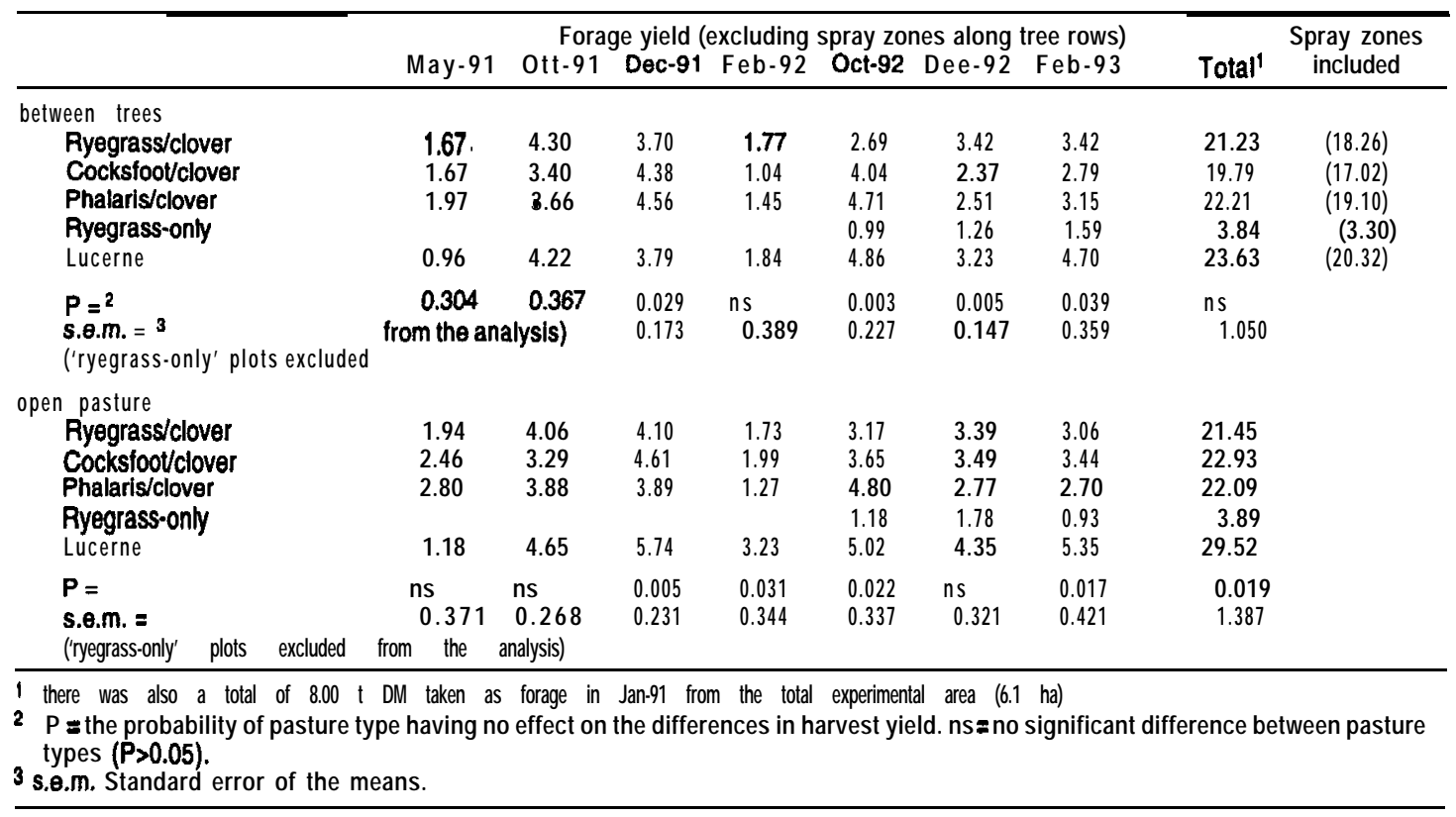

Table 2 Pasture accumulation (t DM/ha) after the last forage harvest.

\begin{tabular}{|c|c|c|c|c|c|c|c|c|}
\hline & \multicolumn{4}{|c|}{ in trees } & \multicolumn{4}{|c|}{ open pasture } \\
\hline & Mar-93 & May-93 & Jun-93 & Sep93 & Mar-93 & May-93 & Jun-93 & Sep-93 \\
\hline $\begin{array}{l}\text { Ryegrass/clover } \\
\text { Cocksfoot/clover }\end{array}$ & $\begin{array}{l}1.83 \\
1.62\end{array}$ & $\begin{array}{l}1.62 \\
2.21\end{array}$ & $\begin{array}{l}1.60 \\
2.35\end{array}$ & $\begin{array}{l}2.21 \\
2.49\end{array}$ & $\begin{array}{l}1.85 \\
1.75\end{array}$ & $\begin{array}{l}1.33 \\
1.64\end{array}$ & $\begin{array}{l}1.19 \\
2.03\end{array}$ & $\begin{array}{l}1.25 \\
1.87\end{array}$ \\
\hline Phalaris/clover & 1.36 & 1.53 & 1.81 & 2.53 & 1.45 & 1.41 & 1.92 & 2.27 \\
\hline Ryegrass-only & 1.43 & $1 . \overline{76}$ & 1.88 & 2.25 & 1.38 & 1.45 & 1.25 & 1.29 \\
\hline Lucerne & 2.57 & 2.21 & , & 3.60 & 3.18 & 3.04 & - & 3.41 \\
\hline$P=$ & 0.003 & \multicolumn{2}{|c|}{0.051 ns } & 0.001 & 0.601 & 0.061 & 0.030 & 0.061 \\
\hline s.e.m. = & 0.149 & 0.166 & 0.176 & 0.149 & 0.203 & 0.185 & 0.178 & 0.215 \\
\hline
\end{tabular}

transformed prior to analysis and the means backtransformed. As it is inappropriate to back-transform standard error data, actual probabilities of the $\mathrm{F}$ test only are reported where these transformations have been used.

\section{Results}

\section{Forage production}

Forage production in the first three years is given in Table 1. Data for the ryegrass-only pasture are included for comparison but were not included in the statistical analysis. There was little pasture growth hence no forage harvest taken in May 1992 (autumn of year 2) after a dry late summer-autumn (Figure 1). Lucerne was the most productive in the open pasture but had similar production to the other grass/legume pastures in the trees. There was relatively low ryegrass/clover production in the spring of year 3 following a heavy infestation of grass grub (Costelytra zealandica) the previous autumn-winter. The comparison of experiment $\mathbf{A}$ and $\mathbf{B}$ over the three years suggests that the trees-had little effect on the forage production except perhaps for luceme. The overriding effect was the $14 \%$ loss of area for forage production in the tree-pasture experiment due to the herbicide-treated zones along the tree rows.

\section{Herbage accumulation after the last harvest}

Regrowth after the February 1993 forage harvest was intended for late autumn pasture. However, difficulty in obtaining sheep to commence grazing at this stage meant that the pasture was left to accumulate until the following spring (Table 2). The lucerne shoots died back in late autumn and no measurement was taken in 
Figure 2 Composition of the harvested forage from the pasture-tree experiment on the left and the open pasture on the right.
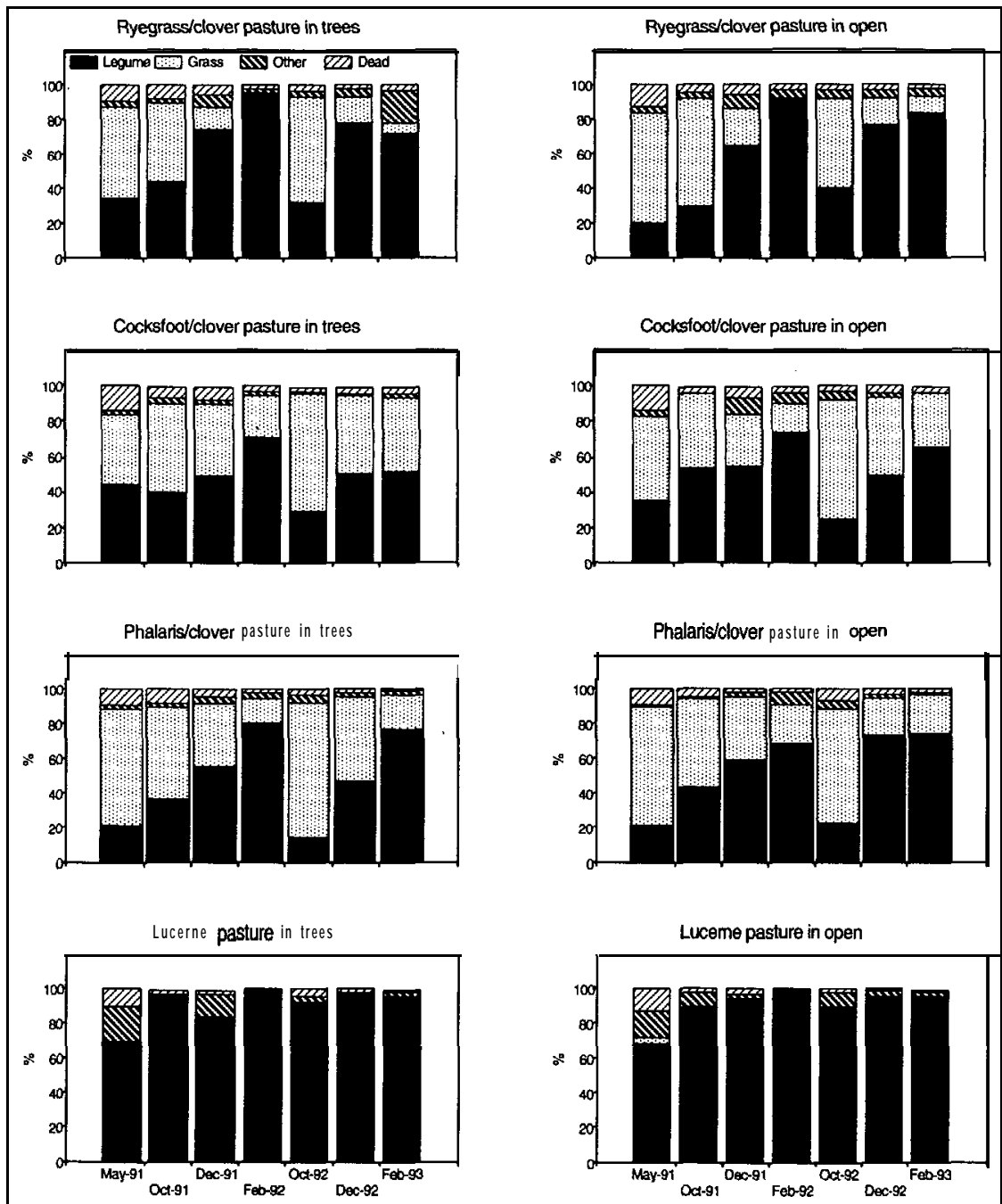

June. New luceme shoots appeared in July and growth was rapid in late September. Cocksfoot grew well in late autumn but was slow to respond in early spring. Ryegrass performed better in the trees than in the open over winter. Phalaris grew better than the other grass/ clover pastures over winter in the open, but in the trees ryegrass performance trees was not far behind.

\section{Botanical composition}

The forage harvesting regime of only 2 or 3 cuts per season favoured the red clover in the grass/clover mixtures, especially in mid summer (Figure 2). Analysis of the grass/clover mixtures showed that clover content was mostly unaffected by the type of sown grass. Discernible differences at the $\mathrm{P}=0.05$ level occurred only in the May-91 and Dee-91 harvest in the trees and in Feb-92 and Feb-93 in the open. For the same harvests and also for the Dee-92 and Dee-93 harvests in the trees, the grass content was discernibly different. By the third year cocksfoot and phalaris tended to dominate more than ryegrass in the grass/clover mixtures. After the grass grub infestation in the autumn/winter of 1992 the clover component of the grass/clover mixtures was almost entirely red clover with little weed invasion except into the ryegrass in the trees. Plant species which most frequently contributed to 'others' were Poa annua, Viola spp., dock (Rumex obtusifolius), wireweed (Polygonum aviculare), yarrow (Achillea millefolium) and couch (Agropyron repens). 
Table 3 Height $(\mathrm{cm})$ and stem diameters $(\mathrm{mm})$ at end of year 3 and relative growth rates calculated as current year's height and stem base diameter increment relative to values at start of the year.

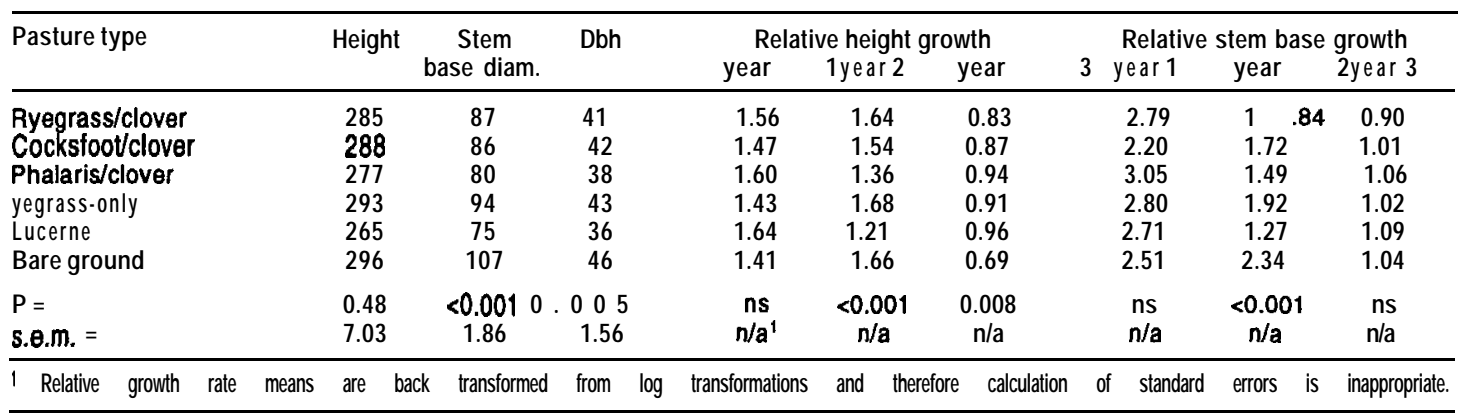

Table4 Pasture biomass (kg DM/ha) in third summer and autumn in relation to distance south and north of tree rows. P I0.001 for the interaction between pasture type and position effects for both dates.

\begin{tabular}{|c|c|c|c|c|c|c|c|c|c|c|}
\hline \multirow[b]{2}{*}{ Pasture type } & \multicolumn{10}{|c|}{ Position relative to nearest tree row } \\
\hline & \multicolumn{5}{|c|}{ menoman... 3 February 1993} & \multicolumn{2}{|c|}{$0.9 \mathrm{~m} \mathrm{~s} 1.8 \mathrm{~m} \mathrm{~s}$} & \multicolumn{2}{|c|}{$\begin{array}{l}2 \text { March } 1993 \\
\text { Centre } 1.8 \mathrm{~m} \mathrm{~N}\end{array}$} & $0.9 \mathrm{~m} \mathrm{~N}$ \\
\hline $\begin{array}{l}\text { Ryegrass/clover } \\
\text { Cocksfoovclover } \\
\text { Phalaris/clover }\end{array}$ & $\begin{array}{l}3160 \\
2926 \\
2939\end{array}$ & $\begin{array}{l}3704 \\
3218 \\
3424\end{array}$ & $\begin{array}{l}3721 \\
3266 \\
3486\end{array}$ & $\begin{array}{l}3401 \\
2970 \\
3155\end{array}$ & $\begin{array}{l}2552 \\
2230 \\
2265\end{array}$ & $\begin{array}{l}2137 \\
1752 \\
1618\end{array}$ & $\begin{array}{l}1890 \\
1686 \\
1437\end{array}$ & $\begin{array}{l}1974 \\
1750 \\
1540\end{array}$ & $\begin{array}{l}1618 \\
1514 \\
1126\end{array}$ & $\begin{array}{c}1381 \\
1266 \\
946\end{array}$ \\
\hline Ryegrass-only & & & & & & 1764 & 1439 & 1567 & 1213 & 1030 \\
\hline Lucerne & 5669 & 6172 & 6204 & 6016 & 5299 & 2321 & 2718 & 2675 & 2577 & 1990 \\
\hline \multicolumn{11}{|c|}{ Standard errors of the means when comparing means from: } \\
\hline $\begin{array}{l}\text { different pasture types } \\
\text { within the same pasture type }\end{array}$ & & & $\begin{array}{c}107.9 \\
40.7\end{array}$ & & & & & $\begin{array}{l}80.9 \\
70.5\end{array}$ & & \\
\hline
\end{tabular}

\section{Tree growth}

After 3 years, tree growth was significantly affected by the type of pasture (Table 3). Relative growth rates for each year (current year's height or stem diameter relative to the respective heights and diameters at the end of the previous year) showed that tree growth was depressed in year 2 in luceme and phalaris/clover, but that the relative growth rates of the trees were similar for all pasture types in the wetter and cooler year 3.

\section{Tree effect on pasture growth}

In year 3, regular inspection of pastures indicated that by January pasture growth within $1 \mathrm{~m}$ of the tree rows was adversely affected. Capacitance probe measurements just prior to the last forage harvest confirmed this (Table 4). Pasture production $0.9 \mathrm{~m}$ south of trees was $\mathbf{1 0 - 1 5 \%}$ less than in the centre and $\mathbf{1 5 - 3 5 \%}$ less at 0.9 $\mathrm{m}$ north of trees with luceme being least affected either north or south of the trees. By March (Table 4) pasture production on the shady side had recovered in all but the luceme. On the sunny side, pasture growth within 1 $\mathrm{m}$ of the trees in all treatments was $25-40 \%$ less than in the centre.

\section{Discussion}

Mead et al. (1993) have indicated the forage production during the first 2 years of this experiment did not differ greatly between pasture types except for the greater production of luceme in the open. The additional data for year 3 in this study confirms that trend. Lucerne is generally regarded as a superior forage plant for dryland pastures especially in drier seasons (White 1982), but adequate moisture can be a problem as seen in the low production in year 2 compared with year 3 . On this site luceme depleted soil moisture more quickly and to a greater depth than ryegrass pastures (Yunusa et al. 1994b).

Forage harvesting as a means of utilising the first three years' production on this site worked well compared with attempts on steeper sites with inadequate room for machinery (Cossens 1984). Our experience showed that forage conservation in young pine plantations is possible on land of suitable topography provided tree spacings and headlands are planned carefully to suit the machinery used. Timber and cut forage is also a land use option where soil is contaminated with high levels of undesirable 
agricultural chemicals, thus intake of contaminated soil by grazing animals can be avoided. Removal of forage will deplete nutrients (a separate study is measuring this) which may have to be replaced. The infrequent cutting in a forage harvest system will generally favour the clovers and change the tillering behaviour of grasses compared with grazing but the greatest disadvantage of prolonged forage harvests is likely to be an increase incidence of pasture pests namely porina and grass grub. Deep-rooted pasture species such as lucerne and phalaris can result in reduced growth of young trees especially in sub-humid climates. Larger herbicidetreated zones around trees may help. Another possibility is to plant pure ryegrass or cocksfoot close to the trees and lucerne in narrow strips centered between rows of trees. This would provide $\mathrm{N}$ to the system, minimise competition with young trees, provide a degree of pest resistance and help to'maintain the grass/legume proportions under a forage harvesting or rotational grazing sytem.

This study uses two approaches to look at the tree effect on pasture/forage production: a) comparison of results from experiment $\mathrm{A}$ and $\mathrm{B}$ and $\mathrm{b})$ variation in pasture growth between the rows of trees. The total forage production was only slightly affected by the presence of trees if the spray zones were not considered. Other reports of tree effects on pasture production (Cossens 1984; Percival et al. 1984a; Knowles et al. 1992) mostly indicate little effect in the first seven years beyond (presumably) the reduction of area due to herbicide application. These studies were conducted in wetter climates than the sub-humid conditions prevalent in the present study. The strong localised depression of pasture growth in the third summer and autumn in these drier conditions indicates that pasture production between trees is likely to decline rapidly as the mean tree crown size increases (Percival \& Knowles 1988). A detailed study of pasture growth and soil moisture undertaken on a subset of the plots in this experiment (Yunusaet al. 1994a,b) showed that lower soil moisture storage close to the trees was a major factor in reducing the pasture growth in the third summer. Later in autumn, a rain shadow on the north side of the trees $(80 \%$ of the measured rainfall was from the southerly quarter) was mainly responsible for the reduced pasture growth immediately north of the trees. A more favourable water balance on the south side of the trees in autumn maintained grass growth but the shading reduced luceme growth.

The depressive effect of luceme and phalaris/clover on tree growth in year 2 (Mead et al. 1993) was not repeated in year 3. This would appear to be a consequence of both the wetter and cooler summer in year 3 and the ability of the trees to intercept sunlight and precipitation causing reduced growth in nearby pasture.

\section{Conclusions}

- Forage harvesting is an option for utilising pasture production on flat land during the tree establishment phase.

- Pasture type is not a major consideration at this stage for forage production but luceme and phalaris adversly affected early tree growth.

- Total herbage production in the first three years on this site was affected little by the trees other than the reduced area caused by herbicide-treated strips for tree establishment.

- At 3 years the competitive advantage of pasture over trees was weakening. It remains to be seen how the pasture will respond to the planned thinning of the trees to 200 trees/ha and pruning.

Further measurements are required to indicate which of the pasture types being tested are most suitable for growing under widely spaced radiata pine trees in the longer term.

\section{ACKNOWLEDGEMENTS}

We thank Bruce Pownall, Don Heffer and Dave Jack for trial maintenance and assistance with measurements. Financial support was provided by Lincoln University and the Foundation for Research, Science and Technology.

\section{REFERENCES}

Cossens, G.G. 1984. Grazed pasture production under Pinus radiata in Otago. In Proceedings of a technical workshop on agroforestry (G.W. Bilbrough, ed.) pp. 39-48. NZ Ministry of Agriculture and Fisheries, Wellington.

Knowles, R.L.; Hawke, M.F.; Maclaren, J.P. 1992. Agroforestry research at Tikitere. Agroforestry Research Collaborative. Report No. 19. NZ Forest Research Institute, Rotorua.

Mead, D.J.; Lucas, R.J.; Mason, E.G. 1993. Studying interactions between pastures and Pinus radiata in Canterbury's sub-humid temperate environment the first two years. NZ Forestry: 26-3 1.

Percival, N.S.; Bond, D.I.; Hawke, M.F.; Cranshaw, L.J.; Andrew, B.L.; Knowles, R.L. 1984a. Effects of radiata pine on pasture yields, botanical composition, weed populations, and production of a range of grasses. In Proceedings of a technical workshop on agroforestry (G.W. Bilbrough, ed.) 
pp. 13-22. NZ Ministry of Agriculture and Fisheries, Wellington.

Percival, N.S.; Knowles, R.L. 1988. Relationship between radiata pine and understory pasture production. In Agroforestry symposium proceedings, 24-27 Nov 1986. (P. Maclaren, ed.) pp. 152164. Bulletin No. 139. Forest Research Institute, Rotorua.

White, J.G.H. 1982. Lucerne grazing management for the 80's. In Lucerne for the 80's (R.B. WynnWilliams, ed.) pp. 11 1-l 14. Special Publication No. 1. Agronomy Society of New Zealand.
Yunusa, I.A.M.; Mead, D.J.; Lucas, R.J.; Pollock, K.M. 1994a. Ecophysiology of a Pinus radiata - pasture agroforestry system in a sub-humid temperate environment. I. Growth of trees and pastures in the third year. Agroforestry systems: In prep.

Yunusa, I.A.M.; Mead, D.J.; Lucas, R.J.; Pollock, K.M. 1994b. Ecophysiology of a Pinus radiata - pasture agroforestry system in a sub-humid temperate environment. II. Storage and use of soil moisture in the third year. Agroforestry systems: In prep. 